\title{
Bacterioplankton growth in seawater: II. Organic matter utilization during steady-state growth in seawater cultures
}

\author{
Å. Hagström*, J. W. Ammerman, S. Henrichs** and F. Azam \\ Institute of Marine Resources, A-018, Scripps Institution of Oceanography, University of California, San Diego, La Jolla, \\ California 92093, USA
}

\begin{abstract}
The objective of this study was to examine the coupling between production of dissolved organic matter in the sea and its utilization by bacteria. We found that growth of natural assemblages of marine bacteria could be sustained in continuous cultures supplied with particle-free $(0.22 \mu \mathrm{m}$ filtered), unsupplemented seawater. Bacteria grew at generation times of 6 to $39 \mathrm{~h}$, showing the ability of the mixed population to use the dissolved organic matter pool at both low and high growth rates. Control experiments with submerged glass coverslips suggest that wall growth was not significant. Bacteria removed $63 \%$ of the total dissolved carbohydrates and $34 \%$ of the total dissolved amino acids from the inflow. At a dilution rate of $0.11 \mathrm{~h}^{-1}$ ( $6 \mathrm{~h}$ doubling time) this carbon consumption was sufficient to account for the entire biomass production even if no other substrates were utilized. High turnover rates of L-leucine and L-glutamic acid ( 8 times $\mathrm{h}^{-1}$ ) could maintain these amino acids at subnanomolar concentrations, in spite of rapid protein hydrolysis. These results suggest that at least some bacteria in the sea can grow rapidly at the expense of ambient levels of dissolved organic matter. Such bacteria may be responsible for the exceedingly low dissolved organic matter concentration found in seawater.
\end{abstract}

\section{INTRODUCTION}

Unattached marine bacteria can grow rapidly in batch mode, at the expense of dissolved organic matter (DOM) in particle-free $(0.22 \mu \mathrm{m}$ filtered) seawater (Ammerman et al., 1984). These growth rates were comparable to instantaneous growth rates for natural assemblages of marine bacterioplankton (as measured by frequency of dividing cells [FDC] or thymidine incorporation; Hagström et al., 1979; Fuhrman and Azam, 1980, 1982; Larsson and Hagström, 1982). These observations are consistent with a scenario of organic matter-bacterioplankton interactions in which the role of particulate organic matter (POM) is mainly as the source of DOM (with only a minor role as a site for bacterial growth). The flux of material and energy through bacterioplankton is thus likely to be controlled by the rates of input of DOM from particulate sources

- Permanent address: Department of Microbiology, University of Umeå, S-901 87 Umeå, Sweden

- Present address: Institute of Marine Sciences, University of Alaska, Fairbanks, Alaska 99701, USA and molecular transformations within the DOM pool to supply utilizable organic matter (UDOM) for bacterial growth.

In order to study the dynamics of this pathway it is necessary to determine the relation between the supply of DOM and bacterial growth. It is also of interest to elucidate changes in the seawater chemistry resulting from bacterial growth. In the past, due to lack of sensitive analytical procedures to measure bacterial nutrients in seawater, such studies were not possible. With the advent of high pressure liquid chromatography (HPLC), methods for measuring free and total amino acids in seawater (Lindroth and Mopper, 1979 Mopper and Lindroth, 1982) have become available. A sensitive method for measuring carbohydrates in seawater is now also available (Burney and Sieburth, 1977; Johnson et al., 1981). There is evidence that these DOM components account for a major part of the bacterial nutrients in seawater (Hollibaugh et al., 1980; Burney et al., 1981).

In this paper we examine the bacteria-DOM interaction by supplying DOM in a dynamic fashion, either in semi-continuous pulses or in a continuous manner to 
achieve a balance between DOM supply and its utilization for bacterial metabolism (mineralization and growth). The experimental system makes use of our experience with mixed marine bacteria in continuous culture and the seawater culture concept (Hagström et al., 1979; Ammerman et al., 1984).

In a brief study, Weyland (1966) reported steadystate growth of a marine Vibrio in a turbidostat supplied with sterile-filtered seawater. Other previous attempts to achieve sustained growth of marine bacterioplankton in continuous cultures fed particle-free unenriched seawater have not been successful. Jannasch (1969) found that growth occurred, but the dilution rate always exceeded it and the cells eventually washed out. Growth rate was calculated as difference between dilution and washout rates. For our purpose, however, it was necessary to achieve sustained growth so that the properties of the cells and of the growth medium could be monitored. The initial goal of this study, therefore, was to establish such an experimental system.

\section{MATERIALS AND METHODS}

Continuous culture. The growth vessel consisted of a $250 \mathrm{ml}$ Pyrex glass suction flask placed inside a ther mostated chamber maintained at $20^{\circ} \mathrm{C} \pm 0.5 \mathrm{C}^{\circ}$ (Fig. 1)

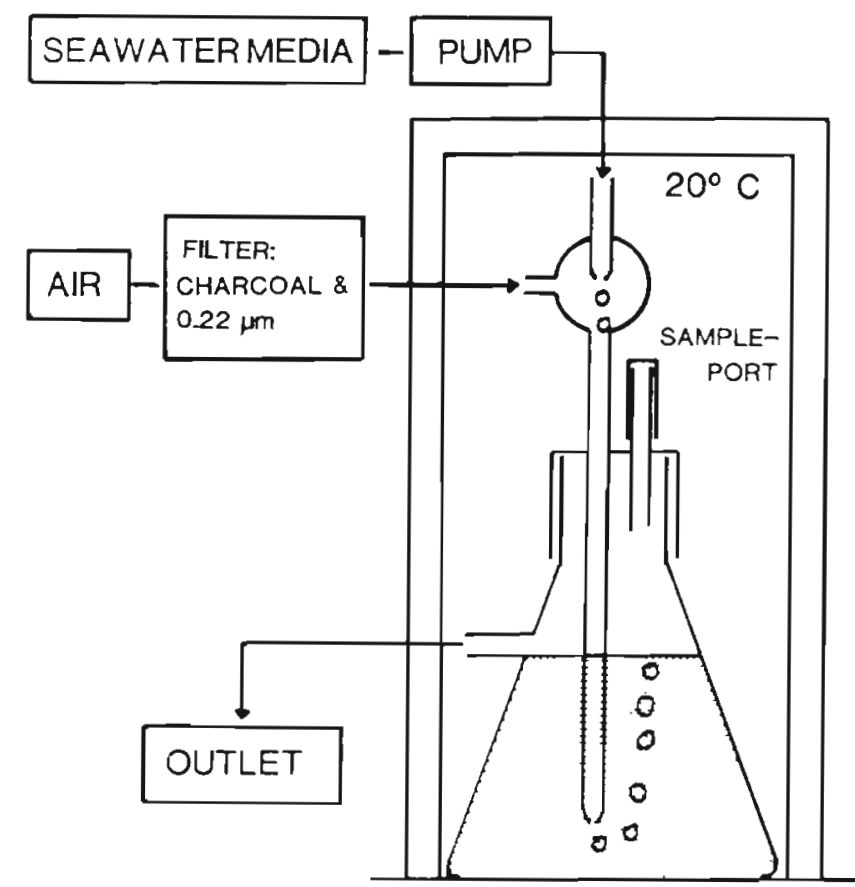

Fig. 1. Continuous culture apparatus used for growing mixed marine bacteria in a continuous seawater culture. The culture vessel (standard glass [Pyrex] suction flask) was kept inside a thermostated chamber. The low cell density $\left(10^{5} \mathrm{ml}^{-1}\right)$ made vigorous stirring for aeration unnecessary; instead, air supply produced the turbulence needed to maintain mixed conditions
All tubing used was made of silicone rubber. The inflow of particle-free seawater was controlled with an LKB Varioperpex II peristaltic pump and was fed dropwise through a glass bulb on the inlet tube. A gentle stream of air, filtered sequentially through a charcoal and 0.22 Millipore (GS) filter, was used to force the inflow into the culture. This was important for preventing a water column from building up in the inflow tube and consequent growth within this tube. The air also served to stir the culture with a continuous stream of small bubbles. There was no evidence of particle formation due to this gentle bubbling (Riley, 1963), though such particle formation cannot be completely ruled out.

The seawater medium for these experiments was collected from Scripps pier and filtered through a GF/ $C$ glass-fiber filter followed by a $0.22 \mu \mathrm{m}$ Millipore (GS) filter in two $142 \mathrm{~mm}$ filter holders connected in series. This set-up allowed filtration of 10 to $20 \mathrm{l}$ seawater within $1 \mathrm{~h}$, thus minimizing the possibility of significant changes in the concentrations of the labile organics. The inflow reservoir containing filtered seawater was then joined to the growth chamber and the entire apparatus was autoclaved at $121^{\circ} \mathrm{C}$ for $60 \mathrm{~min}$. In batch cultures equal yields of bacteria were obtained in $0.22 \mu \mathrm{m}$ filtered seawater whether autoclaved or not (Ammerman et al., 1984). The inoculum $(30 \mathrm{ml})$, derived from Scripps-pier seawater filtered through a $1 \mu \mathrm{m}$ Nuclepore filter, was transferred to the empty culture vessel as the media flow was turned on.

Frequency of dividing cells. Frequency of dividing cells (FDC), a measure of bacterial growth rate, was determined by the method of Hagström et al. (1979). Five $\mathrm{ml}$ of culture were withdrawn aseptically from the growth chamber and transferred to vials containing $0.4 \mathrm{ml}$ of a mixture of ethidium bromide $(0.8 \% \mathrm{w} / \mathrm{v})$, formaldehyde $(20 \% \mathrm{w} / \mathrm{w})$, and hexamethylenediamine $(20 \% \mathrm{w} / \mathrm{v})$. Samples were kept refrigerated until processed. Bacterial abundance and FDC were determined in an epífluorescence microscope. Mean cell size was determined from photomicrographs using a digitizer

Uptake of L-leucine and L-gIutamic acid. Uptake of ${ }^{3} \mathrm{H}$-labeled substrates by bacterial assemblages in the continuous culture was measured according to Azam and Holm-Hansen (1973). The time-course of uptake was determined by measuring both ${ }^{3} \mathrm{H}$ appearance in the cells (uptake) and ${ }^{3} \mathrm{H}$ disappearance from the medium (removal). Samples $(20 \mathrm{ml})$ were removed aseptically from the continuous culture (dilution rate, $\mathrm{D}=0.11 \mathrm{~h}^{-1}$ ) and incubated with 0.4 or $0.6 \mathrm{nM}$ added L- $\left[{ }^{3} \mathrm{H}\right.$ )leucine (52 Ci $\mathrm{mmol}^{-1}$ ). One $\mathrm{ml}$ subsamples were taken at 30 to $60 \mathrm{~s}$ intervals for $12 \mathrm{~min}$, filtered on $0.45 \mu \mathrm{m}$ Millipore filters, and washed twice with icecold filtered seawater. The radioactivity on the filter as 
well as that in the filtrate were determined. The uptake of $\mathrm{L}-\left[{ }^{3} \mathrm{H}\right]$ glutamic acid (9 $\mathrm{Ci} \mathrm{mmol}{ }^{-1}$ ) was determined similarly but after a single 5 min incubation period.

Concentration-dependence of L-leucine uptake. Kinetics of L-leucine uptake were determined by the method of Wright and Hobbie (1965) as modified by Azam and Hodson (1981). Uptake of L-leucine was measured over a broad range of added substrate $\left(9 \times 10^{-10}\right.$ to $\left.9 \times 10^{-6} \mathrm{M}\right)$. Two to 3 replicate $1 \mathrm{ml}$ samples of the continuous culture were incubated for 1 min, filtered, washed, and radioassayed as above. The uptake of ${ }^{3} \mathrm{H}$ was expressed as the turnover rate and graphed according to the modified Eadie-Hofstee plot (Azam and Hodson, 1981) to calculate $V_{\max }$ and $\mathrm{K}_{\mathrm{t}}+\mathrm{S}_{\mathrm{n}}$ (where $\mathrm{S}_{\mathrm{n}}=$ ambient concentration of $\mathrm{L}$ leucine).

Methemoglobin turnover rate. This was determined by the method of Hollibaugh and Azam (1983). Samples (10 to $20 \mathrm{ml}$ total) from the continuous culture were incubated with $0.3 \mu \mathrm{gl}^{-1}\left[{ }^{14} \mathrm{C}\right]$ methemoglobin (17 $\mu \mathrm{Ci} \mathrm{mg}{ }^{-1}$; New England Nuclear, Boston, Mass.). A parallel sample of $0.22 \mu \mathrm{m}$ filtered seawater served as the control. At intervals, $1 \mathrm{ml}$ subsamples were treated with $5 \%$ ice-cold TCA and the rate of appearance of TCA soluble radioactive material was determined as a minimum estimate of the rate of methemoglobin utilization.

Quantitative analysis of amino acids and carbohydrates. Dissolved free amino acids (DFAA) were measured by HPLC, using precolumn derivatization with o-phtaldialdehyde (Lindroth and Mopper, 1979). Total amino acids (TAA) were measured after hydrolysis to amino acids by heating in $6 \mathrm{~N} \mathrm{HCl}$ at $110^{\circ} \mathrm{C}$ for $24 \mathrm{~h}$ in $\mathrm{N}_{2}$-filled ampoules. (The DFAA, generally a very small percentage of the total [see 'Results'], is included in the TAA.) Total carbohydrates (TCHO) were measured by the method of Burney and Sieburth (1977).

\section{RESULTS}

\section{Growth in semi-continuous culture}

As shown earlier (Ammerman et al., 1984), batch seawater cultures generally grow until the bacterial abundance reaches 2 to $3 \times 10^{6} \mathrm{ml}^{-1}$. Before attempting to achieve sustained growth in continuous culture we asked whether batch growth ceases due to nutrient depletion or some other factor. Fig. 2 shows that halving the cell-density by dilution with filtered seawater (Culture A) led to faster growth than in Culture B where bacteria from one-half of the culture were filtered out and the filtrate added to the other half. The generation time in Cultures $\mathrm{A}$ and $\mathrm{B}$ was $13.8 \mathrm{~h}$ and $20.0 \mathrm{~h}$, respectively. Upon second dilution the genera-

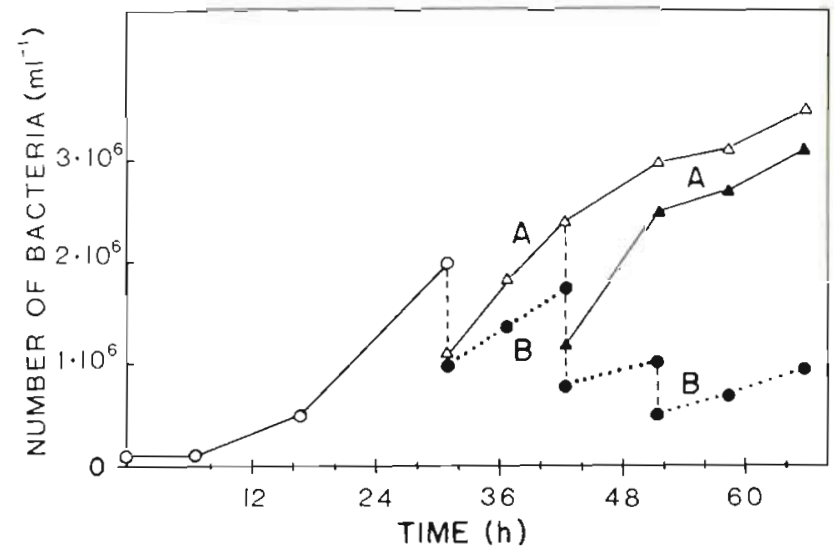

Fig. 2. Bacterial numbers during growth in semi-continuous seawater cultures. Curve A, 2 -fold dilution with fresh filtered seawater, initial culture $(O)$, first dilution $(\Delta)$, second dilution (A). Curve B, removal of half the bacteria by filtration, initial culture (O), successive filtrations indicated with dotted lines $(\bullet)$

tion time in Culture A decreased further to $8.4 \mathrm{~h}$ whereas the generation time in Culture B increased to $23.9 \mathrm{~h}$. The progressive diminution of the growth rate of Culture B as contrasted with the sustained growth of Culture $A$ is seen in Fig. 2 as a gradual decrease in slope of Curve B compared with Curve A. These data indicate that rapid growth of bacteria in seawater cultures could be sustained by dilution with fresh particle-free seawater.

The data in Fig. 2 in themselves do not pinpoint the cause of growth cessation in batch seawater cultures, since faster growth of Culture A could also have been due to the dilution of inhibitory substances. In other nutrient enrichment experiments (without culture dilution; Azam, unpubl.) we found that addition of $1 \mu \mathrm{M}$ glutamic acid stimulated the growth of stationary state seawater cultures. We thus tend to favor nutrient depletion as the cause of the cessation of culture growth, but cannot rule out the alternate possibility above.

\section{Continuous culture}

From this semi-continuous culture we extended our observations to the relation between marine bacterial growth and the rate of supply of DOM in a continuous culture fed particle-free seawater. The first continuous culture was run for $24 \mathrm{~d}$. Numbers of bacteria growing in the culture during the experiment are shown in Fig. 3. The continuous culture was run at 3 different dilution rates. Signs of washout appeared at each change of the dilution rate, after which the population recovered to a new steady state between 1.4 and $4.7 \times 10^{6}$ bacteria $\mathrm{ml}^{-1}$.

After an initial increase in average cell volume, bacteria in the culture remained about the same size 


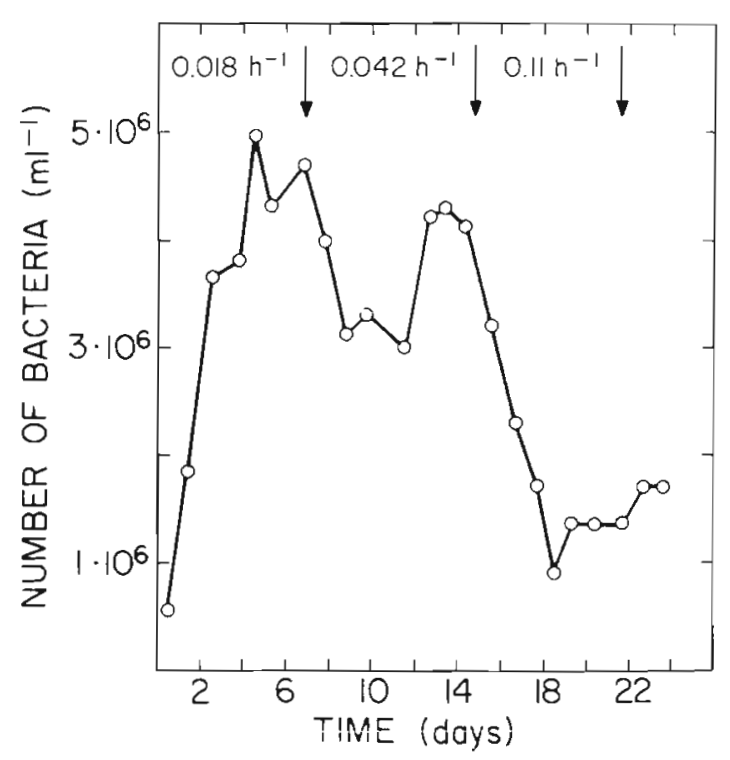

Fig. 3. Bacterial numbers during continuous growth of pelagic bacteria in unsupplemented seawater. Particle-free seawater was used as substrate for a continuous culture inoculated with a mixed assembly of marine bacteria and run for $24 \mathrm{~d}$. All 3 arrows indicate sampling for uptake and growth rate determinations, the first 2 also show the shift to next dilution rate

after 30 divisions in particle-free medium. The average cell volume was $0.17,0.16$, and $0.18 \mu \mathrm{m}^{3}$ at $\mathrm{D}=0.018$, 0.045 and $0.11 \mathrm{~h}^{-1}$, respectively. In comparison, the cell volume of the inoculum was 0.10 to $0.15 \mu \mathrm{m}^{3}$ (from other measurements off Scripps pier; Fuhrman, 1981; Ammerman et al., 1984). This excludes the possibility of division with no concurrent mass increase as in the starvation experiment described by Novitsky and Morita (1978). The observed generation times of 6 to $39 \mathrm{~h}$ show the ability of the mixed population to grow at the expense of the same DOM pool at both low and high growth rates.

The mixed population maintained considerable morphological diversity, which was obvious from photomicrographs. Further evidence of growth of a mixed marine bacterial population came from plate count data. In the inoculum $0.1 \%$ of the total number of bacteria appeared as colony forming units (CFU) on $\mathrm{CP}$ plates (Carlucci and Pramer, 1957). After $17 \mathrm{~d}$ CFU increased but still accounted for only $3.5 \%$ of the bacteria present in the culture, suggesting the continued presence of many growing bacteria which did not grow on agar plates.

In a second continuous culture experiment growth rate was kept constant $\left(0.05 \mathrm{~h}^{-1}\right)$ for $25 \mathrm{~d}$ to demonstrate the stability of the system (Fig. 4). During the course of the experiment flagellates appeared as a contaminant. Flagellate abundance rose from undetectable to a maximum of $8,000 \mathrm{ml}^{-1}$, accompanied by a crash in bacterial population. This fortuitous perturbation further demonstrated the resilience of the sys-

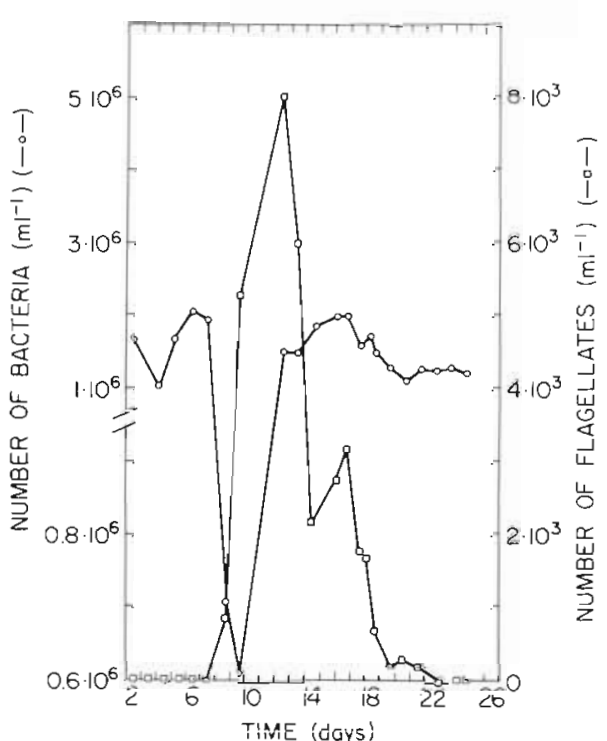

Fig. 4. Bacterial steady-state during continuous growth of pelagic bacteria in unsupplemented seawater. Dilution rate was maintained at $0.05 \mathrm{~h}^{-1}$. Note scale change on left ordinate

tem. As the flagellates declined the system recovered quickly and the bacterial concentration returned to the initial level. Flagellates were counted by epifluorescence microscopy, on the filters prepared for bacterial counts (but at lower magnification, 615X). In unstained samples no autofluorescent cells were found, indicating that all the flagellates were heterotrophic. The flagellates were 2 to $4 \mu \mathrm{m}$ in diameter and biflagellated.

\section{Growth rate measurements}

The bacterial growth rate was monitored in the first continuous culture by the FDC technique (Hagstrom et al., 1979). Table 1 shows that the bacterial assemblage responded to the increased dilution rate with a corresponding increase in FDC. FDC values increased from 0.8 to 2.8 , a range typical of the coastal waters off La Jolla. We could not convert these FDC values into growth rates because no independent calibration curve was available for FDC at $20^{\circ} \mathrm{C}$ (Hagström et al., 1979).

Table 1. Bacterial density and the frequency of dividing cells (FDC) at 3 different dilution rates (D) in a continuous seawater culture

\begin{tabular}{|cccc|}
\hline Day & $\begin{array}{c}\text { D } \\
\left(\mathrm{h}^{-1}\right)\end{array}$ & $\begin{array}{c}\text { Bacteria } \\
\mathrm{m}^{-1}\end{array}$ & $\begin{array}{c}\text { FDC } \\
(\%)\end{array}$ \\
\hline 7 & 0.018 & $4.7 \times 10^{6}$ & 0.8 \\
15 & 0.042 & $4.1 \times 10^{6}$ & 1.5 \\
22 & 0.11 & $1.4 \times 10^{6}$ & 2.8 \\
\hline
\end{tabular}




\section{Wall growth}

In a third culture, with conditions identical to those described above, glass coverslips were submerged to determine wall growth. Cell density on the glass surface showed a slight increase $(10 \%)$ between 1 and $4 \mathrm{~d}$ of exposure. FDC values found on the glass $(2.3 \%)$ did not significantly exceed those in the water $(2.1 \%)$.

\section{Carbohydrate and amino acid pool dynamics in continuous culture}

In order to determine how bacterial metabolism and growth is related to the steady-state concentrations of total carbohydrates and amino acids, we measured these components of the DOM in both the inflow and the outflow at 2 dilution rates (Table 2). (Measurements of these DOM components in both filtered and unfiltered inflow samples [Table 3] showed that nearly all were indeed dissolved or smaller than $0.2 \mu \mathrm{m}$.) The outflow should represent steady-state concentrations in the culture medium. Several observations can be made: (1) At $\mathrm{D}=0.11 \mathrm{~h}^{-1}$, bacteria removed $63 \%$ of dissolved carbohydrate and $37 \%$ of dissolved TAA from the inflow. The amount of carbohydrate utilized (1.7 $\mu \mathrm{M}$ glucose equivalents) was equivalent to $1.2 \times$ $10^{-4} \mathrm{~g} \mathrm{C}^{-1}$. If we assume $5 \times 10^{-14} \mathrm{~g} \mathrm{C}$ bacterium $^{-1}$ (bacteria here were larger than in natural populations) and $50 \%$ assimilation efficiency for carbohydrates, then $1.4 \times 10^{-4} \mathrm{~g} \mathrm{l}^{-1}$ carbohydrate carbon would be required to sustain growth at $\mathrm{D}=0.11 \mathrm{~h}^{-1}(6 \mathrm{~h}$ doubling time). Thus the rate of carbohydrate utilization

Table 2. Total carbohydrate (TCHO; as glucose equivalents) and total combined amino acids (TAA) in inflow and outflow of a seawater continuous culture at 2 different dilution rates (D)

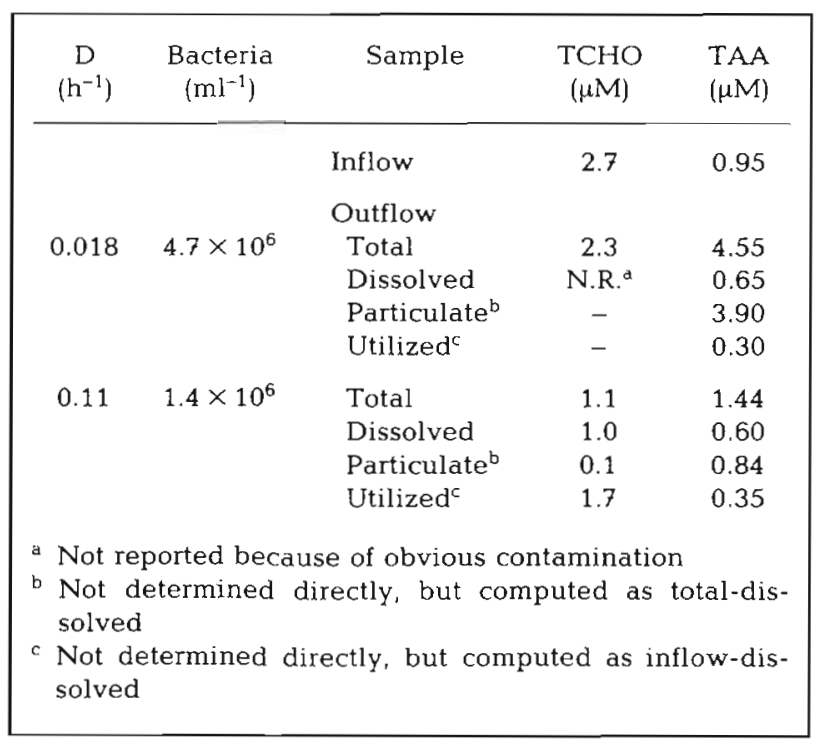

was rapid enough to provide nearly all of the energy and carbon for bacterial growth. The nitrogen in TAA, however, even if assimilated with $100 \%$ efficiency, could have provided only $21 \%$ of the bacterial protein nitrogen (assuming a bacterial $\mathrm{C}: \mathrm{N}$ ratio of 3 , Fuhrman and Azam, unpubl.). Therefore other sources of nitrogen must have been used. (2) At $\mathrm{D}=0.018 \mathrm{~h}^{-1}$ (generation time $39 \mathrm{~h}$ ) there was a much greater accumulation of cells. Here, even if all TCHO in the inflow had been used (at $50 \%$ efficiency) it could account for only $41 \%$ of the carbon required for growth. Therefore, other sources of DOC must have been utilized. Similarly, the amount of TAA utilized (at $100 \%$ efficiency) could have supported a maximum of $5 \%$ of cell growth. Thus other sources of nitrogen, probably ammonium, must also have been utilized.

Table 3 shows that dissolved free amino acids in a comparable sample of Scripps-pier seawater (DFAA; $23 \mathrm{nM}$ ) were less than $3 \%$ of the TAA in the inflow. Thus, most of the TAA removal from the inflow (Table 2) was due to utilization of 'combined' amino acids, which may consist of peptides, proteins, or various types of complexes. Table 3 compares the amount and $\mathrm{mol} \%$ of individual dissolved amino acids in the inflow and the outflow. Quantitatively dominant amino acids in both inflow and outflow were: aspartic acid (asp), glutamic acid (glu), serine (ser), glycine + threonine (gly + thr), and alanine (ala). Of these, glu and ser show large decreases, 41 and $20 \%$, respectively. Thus bacterial metabolism of TAA preferentially utilized glu and ser. The relative concentrations of some minor components increased, probably because they were utilized more slowly than the average for TAA.

Table 3 also lists amino acid abundances in the particulate TAA (presumably only bacteria) at $\mathrm{D}=$ $0.018 \mathrm{~h}^{-1}$ and $0.11 \mathrm{~h}^{-1}$. The non-protein amino acids $\beta$ alanine and $\gamma$-aminobutyric acid $(\gamma$-aba), not surprisingly, were essentially absent in bacteria. (We do not know their source in the inflow.) The relative abundances of amino acids in bacteria were similar at the two dilution rates (except that gly + thr was higher and valine was lower at the faster dilution rate).

\section{Substrate uptake kinetics}

Dissolved protein turnover in the continuous culture was determined as the rate of hydrolysis of added tracer $\left[{ }^{14} \mathrm{C}\right]$ methemoglobin. At $\mathrm{D}=0.11 \mathrm{~h}^{-1}$ (retention time $=9 \mathrm{~h}$ ) the methemoglobin hydrolysis rate was $5 \% \mathrm{~h}^{-1}$ (data not shown), sufficient to account for the measured utilization of $37 \%$ of the TAA in the inflow (Table 2).

L-leucine uptake kinetics were determined to 
Table 3. Total amino acids (TAA) in inflow and outflow of a seawater continuous culture at 2 different dilution rates (D). Dissolved free amino acids (DFAA) are from a comparable sample of Scripps-pier seawater

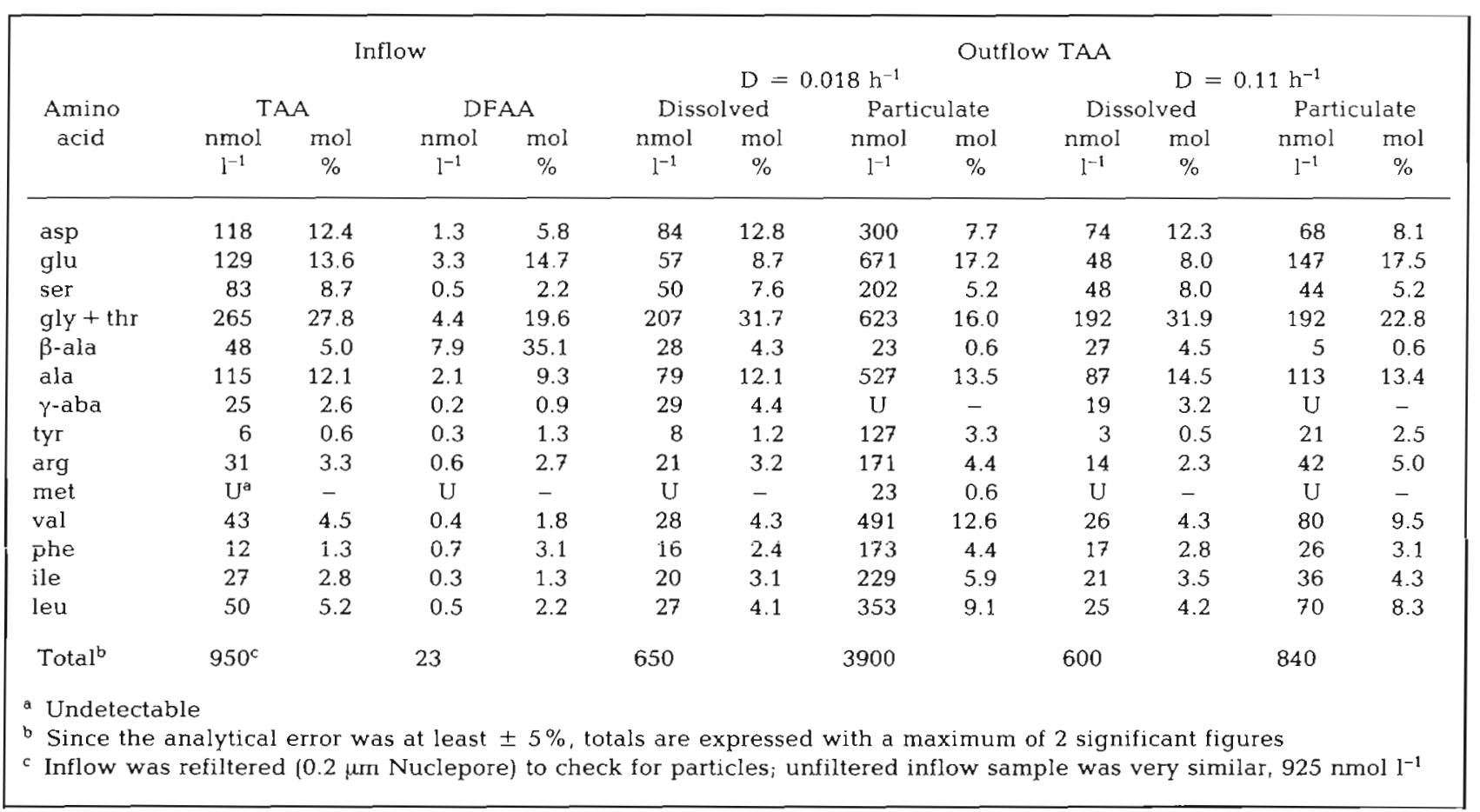

address the question of the ability of bacteria in the continuous culture to utilize very low levels of amino acids present in the inflow effectively. The concentration-dependence of L-leucine uptake (modified EadieHofstee plot; Fig. 5) fit a multiphasic curve with $\left(\mathrm{K}_{\mathrm{t}}+\right.$ $S_{n}$ ) and $V_{\max }$ values of $3 \mathrm{nM}$ and $25 \mathrm{nmol} \mathrm{l}^{-1} \mathrm{~h}^{-1}$, respectively, for the lower range of $[\mathrm{A}]$, and $230 \mathrm{nM}$ and $370 \mathrm{nmol} \mathrm{l} \mathrm{l}^{-1} \mathrm{~h}^{-1}$ for the higher. The activity of the

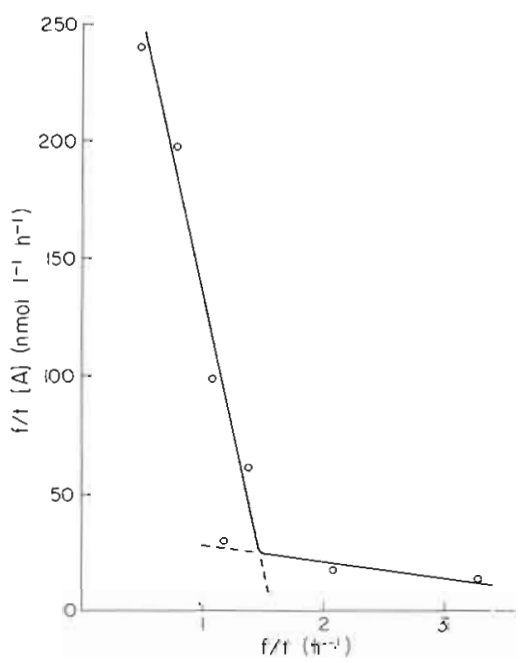

Fig. 5. Eadie-Hofstee inverse plot of leucine uptake kinetics by the continuous culture ( $\left.\mathrm{D}=0.11 \mathrm{~h}^{-1}\right)$. Ordinate: turnover rate times concentration of added substrate $(\mathrm{f} / \mathrm{t} \cdot[\mathrm{A}])$; abscissa: turnover rate $(\mathrm{f} / \mathrm{t})$ low $\mathrm{K}_{\mathrm{t}}$ uptake system was sufficient to take up Lleucine at $3 \mathrm{nmol} \mathrm{l}^{-1} \mathrm{~h}^{-1}$ from $0.5 \mathrm{nM}$ ambient concentration. It is interesting that bacteria which had been growing in particle-free seawater for 30 generations should maintain the high $\mathrm{K}_{\mathrm{t}}$, high $\mathrm{V}_{\max }$ uptake system. This system is either constitutive but not useful in particle-free seawater, or it suggests the presence of high amino acid concentrations in the periplasmic space of gram-negative bacteria due to protein hydrolysis (Hollibaugh and Azam, 1983).

The low $\mathrm{K}_{\mathrm{t}}$ component in Fig. 5 yields a turnover rate for the ambient L-leucine pool of 8 times $\mathrm{h}^{-1}$, about 2 orders of magnitude faster than the dilution rate $\left(0.11 \mathrm{~h}^{-1}\right)$. This suggests that L-leucine inputs are consumed rapidly to maintain low ambient levels. In Fig. 6, L- $\left[{ }^{3} \mathrm{H}\right] l$ leucine added at $0.6 \mathrm{nM}$ (approximating the $0.5 \mathrm{nM}$ concentration in the inflow; Table 2) was rapidly reduced to $0.25 \mathrm{nM}$. A plateau at $0.25 \mathrm{nM}$ was also observed when L-[ $\left.{ }^{3} \mathrm{H}\right]$ leucine was added at $0.4 \mathrm{nM}$. In a separate experiment, the $\mathrm{L}-\left[{ }^{3} \mathrm{H}\right]$ glutamic acid turnover rate was found to be comparable to that for L-leucine (data not shown).

\section{DISCUSSION}

This study establishes that rapid and sustained growth of marine bacteria can be achieved at the expense of natural levels of DOM in seawater. The 


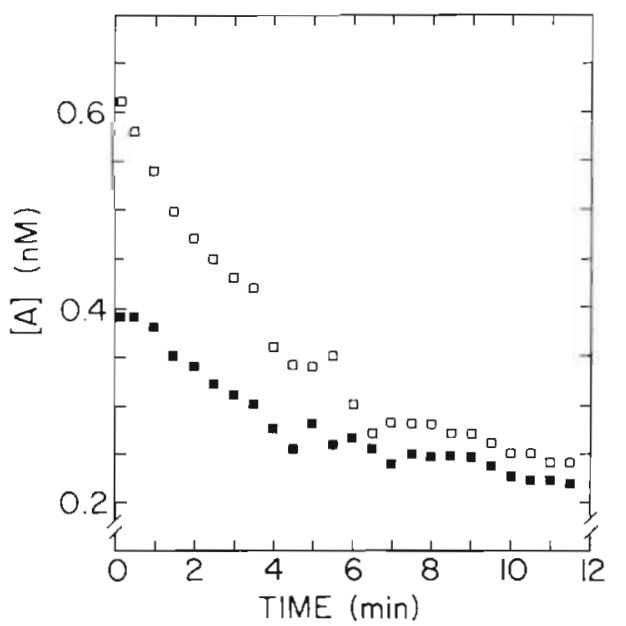

Fig. 6. Time course of disappearance of leucine from continuous culture samples (2 separate experiments $[\square, \mathbf{D}] ; \mathrm{D}=$ $0.11 \mathrm{~h}^{-1}$ for both)

steady-state nutrient concentration at $D=0.11 \mathrm{~h}^{-1}$ was sufficient to sustain a cell-density of $1.4 \times$ $10^{6} \mathrm{ml}^{-1}$, comparable to that found in the coastal euphotic zone. Lower dilution rates led to higher steady-state cell densities $\left(4.7 \times 10^{6} \mathrm{ml}^{-1}\right.$ at $\mathrm{D}=$ $\left.0.018 \mathrm{~h}^{-1}\right)$. Different growth rates of bacteria in the pelagic ecosystem may therefore occur as a result of different rates of input, independent of the quality of the DOM pool. Due to the lack of sensitive analytical procedures to measure specific classes of molecules in the DOM, such studies have until recently been impossible in natural waters. In this study a first step was taken towards an understanding of the biochemical dynamics of substrate utilization that governs bacterial growth in the pelagic ecosystem.

Of the complex mixture of compounds constituting the DOM pool we measured 2 species of macromolecules, TAA and TCHO. DFAA were less than $3 \%$ of TAA. We did not determine what fraction of carbohydrate in the water was monomeric, but other samples from Scripps pier contained $\leq 10 \%$ of the total carbohydrates as free monomers (Henrichs, unpubl.). In Narragansett Bay salt marshes Burney et al. (1981) found values for monosaccharides of around $25 \%$ of TCHO. Diel studies in the salt marsh showed variations in the polysaccharide pool to be greater than for the corresponding monosaccharide fraction, suggesting bacterial hydrolysis and consumption of the polymer. The reduction of total amino acids and probably of carbohydrates in our continuous culture included consumption of the corresponding polymers. The high rate of methemoglobin hydrolysis suggests that bacteria continuously generated amino acids by cell-surface hydrolysis of TAA (see also Hollibaugh and Azam, 1983). The released amino acids were rapidly taken up, as shown for leucine and glutamate, and therefore did not accumulate.
Recently, it has been suggested that most of the bacterioplankton growth is due to free-living bacteria (Fuhrman and Azam, 1982; Tabor and Neihof, 1982; Azam et al., 1983). Thus, our finding here of rapid growth of bacteria on DOM may seem somewhat anticlimactic. Yet, previous attempts to achieve steadystate growth had failed (except Weyland, 1966). Jannasch (1969) attempted to grow 4 different marine isolates on unsupplemented seawater in continuous culture, but steady-states could not be attained. The washout rates, however, were slower than would be expected if no growth had occurred. He concluded that marine bacteria do grow in particle-free seawater but at too slow a rate on the ambient DOM to sustain a steady-state population. Mixed bacterial assemblages (rather than isolates) used in our cultures apparently contained bacteria which could grow rapidly in particle-free seawater. This may explain the difference between our results and those of Jannasch (1969).

Bacteria co-occur with other organisms and detritus and overlap with them in size, chemical composition, and biochemical activity. Such overlap complicates the determination of bacterial growth and cell chemistry. Our interest in studying the biochemistry of bacterial growth has prompted us to seek an experimental system wherein the characteristics of the cells and the growth milieu could be examined and correlated. A common practice is to utilize bacterial isolates grown in pure cultures but the results may not be ecologically valid, since culture characteristics differ greatly from those of the natural system. A more direct approach would be to exclude detritus and all organisms other than bacteria from seawater samples. This is the basis for seawater continuous culture as an experimental system. The limitations and strengths of this experimental system will obviously depend on the questions being addressed, but some general observations are in order.

Continuous culture differs in some fundamental ways from the natural system, both in the properties of the bacterial populations and of the medium. In our experiments, the relative proportions of DOM components in the inflow were constant; only the rate of supply of total DOM could be varied. In the sea, different DOM components may be supplied at different rates. This means that we cannot a priori extrapolate our results to the nutrient-growth relation in the sea. However, different steady-states can be defined in terms of the observed nutrient regimes in the culture and their relation with the observed growth dynamics.

The steady-state populations in our experiment maintained considerable diversity of cell size and morphology even after 30 generations. It is generally believed that in the sea the small bacteria (which constitute a majority of the population) are either dor- 
mant or growing slowly (Stevenson, 1978), whereas much of the growth is attributed to the large and presumably fast-growing cells. In batch seawater cultures (Ammerman et al., 1984) most of the growth appeared to be due to large rods, though some small cocci were always present and possibly growing. In our experiment, small and large cells coexisted at all steady-states, the small bacteria apparently grew as fast as the large ones. However, since we could not enumerate each species separately we cannot be sure whether species-level steady-state was reached in our continuous cultures. It is clear, however, that some small bacteria were capable of growing rapidly, since they persisted at all dilution rates. The increase in the proportion of larger cells in the culture (compared with the inoculum), however, suggests a possible sizeselective removal of the larger cells in the natural system as postulated by Ammerman et al. (1984).

Acknowledgements. We thank E. Fiebig for translation assistance, and M. A. Ogle and D. Osborn for help in manuscript preparation. This work was supported by US Department of Energy contract DE-ATO3-82-ER60031 and National Science Foundation grant OCE79-26458. Further support was provided by the Swedish Natural Science Research Council grant B-PD 4452-106.

\section{LITERATURE CITED}

Ammerman, J. W., Fuhrman, J. A., Hagström, \&., Azam, F. (1984). Bacterioplankton growth in seawater: I. Growth kinetics and cellular characteristics in seawater cultures. Mar. Ecol. Prog. Ser. 18: 31-39

Azam, F., Fenchel, T., Field, J. G., Gray, J. S., Meyer-Reil, L. A., Thingstad, F. (1983). The ecological role of watercolumn microbes in the sea. Mar. Ecol. Prog. Ser. 10: 257-263

Azam, F., Hodson, R. E. (1981). Multiphasic kinetics for Dglucose uptake by assemblages of natural marine bacteria. Mar. Ecol. Prog. Ser. 6: 213-222

Azam, F., Holm-Hansen, O. (1973). Use of tritiated substrates in the study of heterotrophy in seawater. Mar. Biol. 23: 191-196

Burney, C. M., Johnson, K. M., Sieburth, J. McN. (1981). Diel flux of dissolved carbohydrate in a salt marsh and a simulated estuarine ecosystem. Mar. Biol. 63: 175-187

Burney, C. M., Sieburth, J. McN. (1977). Dissolved carbohydrates in seawater. II. A spectrophotometric procedure for total carbohydrate analysis and polysaccharide estimation. Mar. Chem. 5: 15-28

Carlucci, A. F., Pramer, D. (1957). Factors influencing the plate method for determining abundance of bacteria in seawater. Proc. Soc. Exp. Biol. Med. 96: 392-394
Fuhrman, J. A. (1981). Influence of method on the apparent size distribution of bacterioplankton cells: epifluorescence microscopy compared to scanning electron microscopy. Mar. Ecol. Prog. Ser. 5: 103-106

Fuhrman, J. A., Azam, F. (1980). Bacterioplankton secondary production estimates for coastal waters of British Columbia, Antarctica, and California. Appl. environ. Microbiol. 39: 1085-1095

Fuhrman, J. A., Azam, F. (1982). Thymidine incorporation as a measure of heterotrophic bacterioplankton production in marine surface waters: evaluation and field results. Mar. Biol. 66: 109-120

Hagström, §., Larsson, U., Hörstedt, P., Normark, S. (1979). Frequency of dividing cells, a new approach to the determination of bacterial growth rates in aquatic environments. Appl. environ. Microbiol. 37: 805-812

Hollibaugh, J. T., Azam, F. (1983). Microbial degradation of dissolved proteins in seawater. Limnol. Oceanogr. 28 : 1104-1116

Hollibaugh, J. T., Carruthers, A. B., Fuhrman, J. A., Azam, F. (1980). Cycling of organic nitrogen in marine plankton communities studied in enciosed water columns. Mar. Biol. 59: $15-21$

Jannasch, H. W. (1969). Estimations of bacterial growth rates in natural waters. J. Bacteriol. 99: 156-160

Johnson, K. M., Burney, C. M., Sieburth, J. McN. (1981). Doubling the production and precision of the MBTH spectrophotometric assay for dissolved carbohydrates in seawater. Mar. Chem. 10: 467-473

Larsson, U., Hagström, §. (1982). Fractionated phytoplankton primary production, exudate release and bacterial production in a Baltic eutrophication gradient. Mar. Biol. 67: $57-70$

Lindroth, P., Mopper, K. (1979). High performance liquid chromatographic determination of subpicomole amounts of amino acids by precolumn fluorescence derivatization with ophthaldialdehyde. Analyt. Chem. 51: 1667-1674

Mopper, K., Lindroth, P. (1982). Diel and depth variations in dissolved free amino acids and ammonium in the Baltic Sea determined by shipboard HPLC analysis. Limnol. Oceanogr. 27: 336-347

Novitsky, J. A., Morita, R. Y. (1978). Possible strategy for the survival of marine bacteria under starvation conditions. Mar. Biol. 48: 289-295

Riley, G. A. (1963). Organic aggregates in seawater and the dynamics of their formation and utilization. Limnol. Oceanogr. 8: 372-381

Stevenson, L. H. (1978). A case for bacterial dormancy in aquatic systems. Microb. Ecol. 4: 127-133

Tabor, P. S., Neihof, R. A. (1982). Improved microautoradiographic method to determine individual microorganisms active in substrate uptake in natural waters. Appl. environ. Microbiol. 44: 945-953

Weyland, v. H. (1966). Untersuchungen über die Vermehrungsrate mariner Bakterien in Seewasser Veröff. Inst. Meeresforsch. Bremerhaven. 2 (Sbd.): 245-253

Wright, R. T., Hobbie, J. E. (1965). The uptake of organic solutes in lake water. Limnol. Oceanogr. 10: 22-28 